\title{
Peta Politik Pemilukada Kabupaten Ponorogo 2020 di Tengah Pandemi COVID-19
}

\section{Regional Election in Ponorogo Regency: Political Map in The Middle COVID-19 Pandemic}

\author{
Yusuf Adam Hilman', Khoirurrosyidin², Niken Lestarini ${ }^{3}$ \\ 1,2Program Studi Ilmu Pemerintahan, Fakultas Ilmu Sosial dan Ilmu Politik, Universitas \\ Muhammadiyah Ponorogo \\ Jalan Budi Utomo No 10 Siman, Ponorogo Jawa Timur \\ ${ }^{3}$ Program Studi Ilmu Komunikasi, Fakultas Ilmu Sosial dan Ilmu Politik, Universitas \\ Muhammadiyah Ponorogo \\ Jalan Budi Utomo No 10 Siman, Ponorogo Jawa Timur \\ *corresponding author E-mail: adam_hilman@umpo.ac.id
}

Diterima: 8 Juli 2020; Direvisi: 21 Juli 2020; Disetujui: 24 Juli 2020

\begin{abstract}
ABSTRAK
Pemilihan Kepala Daerah yang diselenggarakan tahun 2020 saat ini akan dilakukan dalam kondisi pandemi COVID-19, Kabupaten Ponorogo merupakan salah satunya, pelaksanaan pilkada memberikan tantangan terkait praktik demokrasi dan menjaga masyarakat supaya aman sesuai protokol kesehatan yang baik. Penelitian ini bertujuan untuk melihat seberapa besar peluang peserta dalam Pilkada, selain itu bagaimana kesiapan mereka. Metode penelitian adalah deskriptif kualitatif, dengan mengumpulkan data sekunder dari pemberitaan media dan juga hasil penelitian, data yang terkumpul kemudian diuji keabsahan menggunakan triangulasi. Hasil penelitian memperlihatkan ada 2 (dua) calon kepala daerah yang diprediksi akan maju, yang pertama adalah Ipong Muhlisoni yang merupakan calon Incumbent, yang kedua adalah salah satu tokoh masyarakat yang pada periode pilkada sebelumnya menjadi pesaing yakni Sugiri Suncoko. Melihat pemilukada di era pandemi COVID-19, banyak hal yang harus diperhatikan oleh pihak penyelenggara pemilu, kandidat bupati dan calon bupati, serta massa pendukungnya, yakni mematuhi protokol kesehatan dan juga menjaga nilai pokok dari praktik demokrasi supaya dapat terpenuhi, yakni: transparan, profesional dan dapat dipertanggungjawabkan. Melihat kandidat yang muncul, sepertinya belum siap mengikuti pemilukada di tengah Covid 19.
\end{abstract}

Kata kunci: COVID-19, Pemilukada, Peta Politik

\section{ABSTRACT}

The regional election held in 2020 when will be carried out in a condition of pandemic covid-19, Ponorogo regency is one of them, the election gives challenges related to the community so that democracy practices and keeps safe 
in accordance with good health protocol. This study attempts to identify the likely participants in the election, In addition they show readiness. The Qualitative research methodology is descriptive, on secondary data from media sources and the research, the data collected and tested the validity of using triangulation. The results show 2 (two) prospective regional leaders who predicted to go forward, The First Is Ipong Muhlisoni that is the incumbent, The second is one of the community figures in the period election earlier to competitors are Sugiri Suncoko. See the upcoming general election in the era of pandemics covid - 19, a lot of things that must be considered: the committee for the general election, A regency is headed by a regent, and prevent the practices value the essence of democracy that could be met, and this is: transparent, profesional and could be accounted for. See the candidates that appear, seem to have not are ready to follow the upcoming general election in the middle of covid-19.

Keyword: COVID-19, Regional Election, Political Map

\section{PENDAHULUAN}

Kedaulatan Negara berada di tangan rakyat, begitulah amanat konstitusi yang menginginkan seluruh warga Negara berperan serta secara aktif dalam memilih pemimpin. Dalam Undang-Undang Dasar 1945 Pasal 1 ayat (2), yang berbunyi: "kedaulatan berada di tangan rakyat dan di laksanakan menurut undang-undang dasar", kaidah undang-undang menerangkan jika praktik kedaulatan diterjemahkan dalam bentuk pemilihan langsung di berbagai level pemerintahan, mulai dari memilih pemimpin negara, pemimpin daerah, hingga memilih legislator. Instrumen dalam pemilihan pemimpin juga dijelaskan dalam undang-undang pemilu nomor 7 tahun 2017, yang menegaskan bahwa pemilihan umum adalah sarana dalam mewujudkan kedaulatan masyarakat.

Secara sederhana kedaulatan rakyat adalah pemerintahan di bawah rakyat, atas mandat rakyat, sehingga kekuasaan tertinggi di bawah kuasa rakyat, melalui pemimpin yang dipilih oleh rakyat (Fahmi, 2010).

Prinsip kedaulatan yakni menempatkan masyarakat dengan porsi yang cukup, untuk memainkan peranan dalam proses pengambilan keputusan termasuk dalam menentukan serta memilih pimpinan, tentunya tanpa adanya hegemoni dalam pembuatan peraturan oleh para penguasa, melalui praktik pembuatan peraturan yang merugikan masyarakat dan menguntungkan 
pejabat serta pemimpin publik (Rosana, 2016).

Partisipasi dalam konsep kedaulatan rakyat kemudian diterjemahkan dalam bentuk praktik demokrasi langsung direct democracy yang benar-benar memposisikan masyarakat secara total dalam proses penentuan seorang pimpinan publik. Ajang pelaksanaan demokrasi langsung dapat kita lihat dari pesta demokrasi di level pemerintahan lokal atau daerah, disitulah masyarakat diajak berpartisipasi langsung untuk menentukan masa depan di daerahnya masing-masing (Simamora, 2011).

Pada hakikatnya, dalam ide kedaulatan rakyat itu, tetap harus dijamin bahwa rakyatlah yang sesungguhnya pemilik negara dengan segala kewenangannya untuk menjalankan semua fungsi kekuasaan negara, baik di bidang legislatif, eksekutif, maupun yudikatif. Rakyatlah yang berwenang merencanakan, mengatur, melaksanakan dan melakukan pengawasan serta penilaian terhadap pelaksanaan fungsi-fungsi kekuasaan itu. Bahkan lebih jauh lagi, untuk kemanfaatan bagi rakyatlah sesungguhnya segala kegiatan ditujukan dan diperuntukkan segala manfaat yang didapat dari adanya dan berfungsinya kegiatan bernegara itu. Inilah gagasan kedaulatan rakyat atau demokrasi yang bersifat total dari rakyat, untuk rakyat, oleh rakyat, dan bersama rakyat (Noviati, 2013). Di Indonesia, demokrasi berkembang seiring dengan pergolakan politik yang terjadi setelah kemerdekaan. Perubahanperubahan konsep demokrasi terjadi mulai dari demokrasi terpimpin, demokrasi parlementer hingga demokrasi presidensial, namun pada dasarnya, peranan pemerintahan dalam menjalankan demokrasi masih sangat dominan, karena dalam UUD 1945 beserta amandemennya, masih nampak kuat kekuasaan pemerintahan dibanding lainnya (Irawan, 2007).

Secara etimologis, demokrasi berarti kedaulatan ditangan rakyat (demos dan kratos). Sebagai konsep, demokrasi berlaku umum dan universal, namun pada saat diterapkan dalam suatu bangsa/negara maka implementasinya senantiasa terikat oleh kondisi obyektif negara/bangsa yang bersangkutan. Oleh karena itu, demokrasi nuansanya adalah budaya bukan 
ideologi, sehingga berdemokrasi bukan harus seperti yang berkembang di Barat (Tjarsono, 2013). Mengingat dalam demokrasi membuka ruang gerak untuk berbeda pendapat, maka perbedaan itu harus dipandang sebagai modal dasar bagi perkembangan hidup manusia. Oleh karena itu, dalam mengelola perbedaan membutuhkan akal sehat, bukan individu yang bebas maupun individu yang terbelenggu oleh kemasyarakatan. Dengan akal sehat, maka perbedaan akan menjadi berkah bagi kehidupan manusia dalam mewujudkan keadilan dan kesejahteraan hidup dan kehidupan manusia beserta alam lingkungannya (Prabowo, 2011).

Demokrasi pada hakikatnya memberikan hak kepada rakyat untuk memberikan partisipasi dalam menyalurkan kehendak dalam menentukan masa depan mereka. Dalam kondisi ini, hanya penyaluran kehendak secara langsung yang dapat memenuhi syarat untuk disebut demokratis karena mustahil bila satu orang di parlemen yang mewakili sekian ribu orang dapat berbicara berdasarkan kepentingan-kepentingan dari seluruh rakyat yang ia wakilkan. Kedaulatan tidak dapat diwakilkan, dan dengan alasan yang sama tidak dapat pula dipindahkan haknya. Intinya adalah kehendak umum harus berbicara untuk dirinya sendiri atau tidak sama sekali. Tidak mungkin berada di tengahnya. Oleh karena itu para utusan rakyat bukan dan tidak mungkin menjadi wakil rakyat (Setiabudhi, 2015).

Kelembagaan praktik demokrasi langsung di level daerah, telah memulai babak baru ketika muncul ketidakpuasan dari rakyat terkait pemilihan kepala daerah (Pilkada) melalui DPRD, ketidakpuasan tersebut muncul ketika lahirnya Undang-Undang Nomor 22 Tahun 2014 tentang Pemilihan Gubernur, Bupati dan Walikota yang banyak menimbulkan polemik dalam pelaksanaanya. Untuk meredam hal tersebut maka dibentuklah Peraturan Pemerintah Pengganti Undang-Undang Nomor 1 Tahun 2014 tentang Pemilihan Gubernur, Bupati, dan Walikota yang membatalkan aturan sebelumnya (Hardjaloka, 2015).

Pembabakan baru pemilihan kepala daerah pasca lahirnya aturan baru 
POLITICON : Jurnal Ilmu Politik Vol.2 No.2 ; Hal 129-148

Website : http://journal.uinsgd.ac.id/index.php/politicon

ISSN : 2685-6670 ( Online )

yang telah dijelaskan, tidak serta-merta lancar, hal ini dikarenakan munculnya berbagai pengalaman empiris yang menyisakan beberapa polemik baru, hal itu berkaca dari beberapa pengalaman baru yang hadir menyertai masyarakat Indonesia dalam kaitannya pemilihan kepala daerah.

Regulasi Undang-Undang No. 8 Tahun 2015 belum mampu meminimalisir celah politik uang. Masih banyak laporan dugaan politik uang pada pilkada serentak 2015. Selain itu, pelaksanaan pilkada serentak perlu dievaluasi terutama terkait penjaringan calon kepala daerah yang dinilai masih belum terbuka dan demokratis. Surat rekomendasi Dewan Pimpinan Pusat (DPP) Partai merusak semua mekanisme tahapan rekrutmen pencalonan kepala daerah. Nama calon yang diusulkan oleh pengurus partai daerah seringkali patah di tengah jalan dan pada akhirnya yang sangat menentukan adalah tetap rekomendasi DPP bukan pengurus partai di tingkat daerah (Chaniago, 2016).

Ketidakpercayaan publik tersebut lebih dikarenakan tidak konsistennya kontestan yang telah terpilih sebagai pemimpin untuk merealisasikan visi misinya di pemilukada lalu, sehingga membawa dampak timbulnya ketidakpercayaan publik. Sikap apatis warga kemudian "dibeli” melalui pendekatan transaksional sehingga membengkakkan keuangan para kontestan di pemilukada termasuk besarnya keuangan yang dialokasikan pada pengadaan iklan politik atau alat peraga (Sinaga, 2012). Permasalahan penyelenggaraan pemilukada memerlukan intervensi regulatif dan teknis agar pemilukada berproses secara demokratis, penyelenggaraan yang akuntabel, efektif, efisien dalam pembiayaan dan mampu menghasilkan kepala daerah dan wakil kepala daerah yang lebih berkualitas (Nuryanti, 2015).

Penyelenggaraan pemilihan kepala daerah di tengah COVID-19 memang bukan upaya yang mudah (Kennedy \& Suhendarto, 2020). Hasil kajian terdahulu tersebut memperlihatkan bagaimana penyelenggaraan pemilukada masih banyak kekurangan, ada beberapa poin penting yang muncul ke permukaan sebagai sebuah persoalan, diantaranya: 1). Sistem 
rekomendasi partai yang merusak praktik demokrasi langsung, dimana calon yang di usung sering patah oleh rekomendasi dari pusat, 2). Sikap apatis masyarakat karena tidak konsistennya pemimpin yang terpilih atas janji-janji politiknya kepada masyarakat, 3). Persoalan teknis terkait penyelenggaraan pemilukada, sehingga harus ada intervensi dari pemerintah pusat supaya dapat meminimalisir pelanggaran yang terjadi.

Dengan demikian terlihat perbedaan yang mencolok antara kajian yang sudah ada, dengan penelitian yang dilakukan oleh penulis, dimana penulis lebih menekankan bagaimana praktik pemilukada dengan kondisi pandemik Virus Covid-19, dengan berbagai keterbatasan, tetapi harus bisa menjaga prinsip demokrasi.

Problematika yang muncul dan dihadapi pasca lahirnya undangundang tentang pemilihan kepala daerah secara langsung, ternyata dialami juga di seluruh wilayah Indonesia, tak terkecuali pemilihan umum yang dilakukan di Kabupaten Ponorogo. Pilkada yang telah dilaksanakan, memberikan gambaran bahwa dalam pesta demokrasi tersebut, bermunculan persoalan, puncaknya terjadi ketika pasangan nomor urut 1 (satu) Sugiri Sancoko-Sukirno melayangkan gugatan ke MK dengan dugaan sejumlah kecurangan dan kejanggalan, diantaranya: money politik dan penggelembungan suara. Terkait gugatan yang telah masuk di meja MK nomor 34 itu, KPUD Ponorogo memastikan menunda jadwal penetapan hasil pilkada.

Komisi Pemilihan Umum Kabupaten Ponorogo Jawa Timur, menunda pengumuman penetapan pemenang pemilihan kepala daerah. KPU masih menunggu putusan Mahkamah Konstitusi atas gugatan yang dilayangkan pasangan Sugiri Sancoko-Sukirno soal hasil rekapitulasi suara. Dalam rekapitulasi, pasangan Ipong Muchlisoni-Sujarno dinyatakan sebagai pemenang. "Karena ada gugatan, penetapan bupati terpilih yang dijadwalkan 21-22 Desember 2015 diundur menjadi 12 Februari-13 Maret 2016," kata komisioner Divisi Hukum dan Pengawasan KPU Ponorogo, Teguh Wiyono, Selasa, 22 Desember 2015. Menurut dia, penundaan itu dipastikan setelah 
pihaknya menerima surat dari Mahkamah Konstitusi bernomor 119/Pan.MK/XII/2015 tentang keterangan perkara hasil pemilihan bupati atau walikota 2015. Surat itu menyebutkan daerah yang terdapat permohonan sengketa perkara hasil pilkada, salah satunya Ponorogo.

Perkembangan hasil Pemilukada yang telah diselenggarakan di Kabupaten Ponorogo, akhirnya menemui titik akhir melalui penetapan Bupati Terpilih yaitu, pasangan Ipong Muchlisoni-Sujarno, hal ini di jelaskan dalam amar putusan jika gugatan yang dilayangkan oleh pasangan nomor urut 01 (satu) Sugiri Sancoko dan Sukirno dengan nomor 12/PHP.BUP-XIV/2016 tidak memenuhi pokok gugatan, karena secara Legal Standing, hanya terjadi selisih 1 (Satu) persen suara. Hal ini tidak sesuai dengan ketentuan hukum yang tertuang dalam pasal 158 UU nomor 8 tahun 2015 dan pasal 6 PMK 15/2015, batas selisih suara Kabupaten Ponorogo untuk bisa mengajukan gugatan adalah 6,53 persen, sehingga diabaikan karena tidak memenuhi syarat.

Potret tersebut merupakan perjalanan panjang pemilukada langsung yang dilaksanakan di Kabupaten Ponorogo. Beberapa catatan penting diperoleh peneliti, sebagai bentuk resume sederhana, terkait fenomena praktik demokrasi di level daerah, ada beberapa hal yang ingin kami sampaikan, diantaranya: 1). Pasangan terpilih pada pilkada langsung Kabupaten Ponorogo pada tahun 2016, diusung oleh beberapa partai kecil yang tidak memiliki basis massa yang kuat di wilayah Ponorogo, seperti halnya PDIP, 2). Figur calon yang maju walaupun masih baru tetapi memiliki kekuatan finansial yang kuat bisa memenangkan pilkada, 3). Komitmen politik yang dibangun oleh pasangan calon urut nomor 1 (Satu), sehingga terbentuk kepercayaan dari masyarakat terhadap calon yang akan maju.

Pada tahun 2020 tepatnya pada bulan Mei, akan kembali dilakukan Pemilukada langsung di Kabupaten Ponorogo, pada tahun ini banyak sekali isu-isu yang berkembang, yang menurut kami menarik untuk menjadi bahan kajian. Beberapa hal diantaranya: terkait dengan bagaimana arah koalisi partai 
politik, siapa saja kandidat calon bupati yang akan maju dalam pemilukada, selain itu dalam kurun waktu beberapa bulan terakhir, banyak sekali rumor yang berkembang terkait pecahnya koalisi di pemilukada periode yang lalu, bahkan kemunculan beberapa tokoh yang akan maju secara independen atau tidak berangkat dari partai.

Fenomena tersebut akan kami amati untuk mengetahui peta politik pemilukada 2020 di Kabupaten Ponorogo dalam memperoleh gambaran yang kontekstual dengan kondisi di lapangan, sehingga bisa diprediksi atau diperkirakan bagaimana kontestasi tersebut akan berlangsung.

Pesta demokrasi yang akan dilaksanakan oleh Kabupaten Ponorogo pada Tahun 2020, telah banyak memperlihatkan isu-isu atau rumor yang berkembang terkait arah koalisi, kandidat yang akan maju, hingga beritaberita sehubungan pecahnya kongsi atau koalisi diantara para kandidat tersebut Ini akan menarik untuk dikaji secara mendalam. Berangkat dari asumsi tersebut, maka terdapat rumusan masalah bagaimana peta politik pada pemilukada yang akan dilaksanakan pada tahun 2020, selain itu bagaimana peluang dari masing-masing kandidat.

\section{METODE PENELITIAN}

Penelitian tentang Peta Politik Pemilukada Kabupaten Ponorogo 2020, merupakan jenis penelitian kualitatif deskriptif, yang memberikan analisis dari berbagai data primer dan sekunder untuk mengetahui bagaimana peta politik yang akan muncul dalam proses pemilukada di wilayah Ponorogo. Data yang telah dikumpulkan, kemudian dilakukan analisis secara sederhana namun mendalam, dengan beberapa tahapan. Proses analisis dilakukan secara sederhana, diawali dengan proses mengumpulkan data, kemudian membuat identifikasi data sesuai dengan kategorisasi yang diinginkan, sehingga akan menghasilkan analisis yang komprehensif untuk menerka kekuatan politik masing-masing kandidat. Secara kongkrit tahapan penelitian bisa dilihat pada gambar 1.

Salah satu hal yang penting dilakukan adalah melakukan keabsahan data, melalui teknik triangulasi untuk melihat sejauh mana data teruji 
keabsahannya sehingga dapat dipertanggungjawabkan.

Triangulasi adalah salah satu jawaban atas kesahihan riset kualitatif. Menjelang akhir abad ke-19, Egon G. Guba menulis makalah berjudul Criteria for Assessing the Trustworthiness of Naturalistic Inquiries yang terbit pada tahun 1981 dan pada tahun 1985 bersama Yvonna S. Lincoln menerbitkan Naturalistic Inquiry. Dua karya tersebut menjawab keraguan prosedur dan hasil riset kualitatif, khususnya prosedur triangulasi data, triangulasi investigator, triangulasi teori dan triangulasi metodologi (Zamili, 2015).

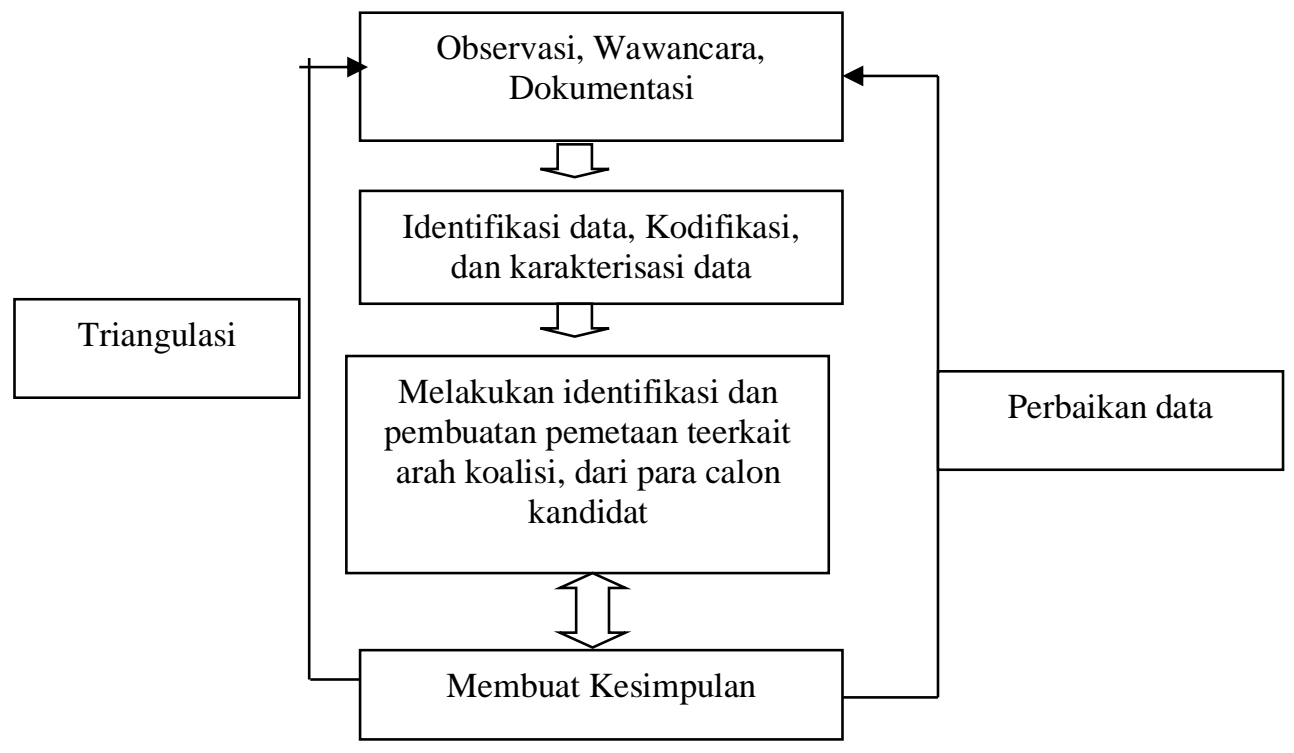

Gambar 1. Skema analisis data

\section{TEMUAN DAN PEMBAHASAN}

Pemilihan umum kepala daerah merupakan bentuk aplikatif dari konsep demokrasi yang dianut oleh negara Indonesia. Praktik Pemilukada resmi dilakukan pada tahun 2005. Pada awal praktik pemilihan tersebut tentunya masih banyak persoalan yang terjadi.

Persoalan pemilukada antara lain: 1). Politik Transaksional (Money Politics) 2). Kampanye Hitam (black campaign), 3). Netralitas Birokrasi, 4). Netralitas Petugas Pemilu, 5). Kapabilitas peserta dan partai politik pengusung calon, 6). Apatisme masyarakat terhadap penyelenggaraan pemilu, 7). Munculnya konflik horizontal ketika momen penyelenggaraan pemilu (Rahmatunnisa, 2017). Tidak hanya itu, kebijakan tentang pemilihan umum 
secara langsung juga dinilai kurang matang sehingga memunculkan persoalan di lapangan, antara lain: 1). Daftar pemilu belum jelas, 2). Sarana-prasarana dan pengawasan tidak memadai, 3). Pengiriman logistik pemilu sering terlambat, 4). Psikologi calon dan pendukung tidak siap, 5). Sosialisasi tidak maksimal, 6). KPU Belum berpengalaman (Hikmat, 2014).

Belum adanya manajemen konflik ketika pemilukada berlangsung, menjadikan konflik yang muncul tidak diselesaikan secara tuntas, hanya menempuh jalur hukum yang tentunya tidak dapat memuaskan semua pihak yang bersengketa (Ramadlan \& Tri Hendra Wahyudi, 2016).

Persoalan yang muncul dalam pelaksanaan pemilihan umum langsung, merupakan salah satu kenyataan yang terjadi di lapangan dan harus dihadapi serta diselesaikan. Berbagai langkah serta upaya juga dilakukan untuk menyelesaikan kondisi tersebut dengan kerumitan dan ganjalan yang seringkali dihadapi, merupakan kewajaran dalam sebuah praktik berdemokrasi.

Upaya menaikkan batas ambang Parlementary Treshold 7-10 \% sehingga partai yang tidak mampu mencapai angka tersebut tidak bisa masuk parlemen merupakan bentuk meminimalisir kepentingan dengan banyaknya partai politik, sehingga mengurangi praktik kecurangan (Aridhayandi, 2015). Pemanfaatan sosial media untuk meminimalisir berita hoax dalam praktik pemilukada menjadi salah satu alternatif yang bisa digunakan. Selain murah teknologi yang sudah menjadi bagian dari masyarakat, menjadi sebuah strategi yang jitu untuk menyampaikan pesan kepada khalayak (Haqqani, 2020).

Mengambil contoh dari penyelenggaraan pemilu dari negara Brazil yang memperlihatkan model kerja serta netralitas lembaga Superior Electoral Court (SEC) seperti BAWASLU di Indonesia yang bergerak secara independen, dengan berbagai prasyarat ketat dalam pengangkatannya yang diambil dari beberapa hakim-hakim terbaik di lembaga Mahkamah Agung dengan durasi jabatan hanya 2 (dua) tahun dan tidak dapat dipilih lagi, menunjukkan 
bagaimana integritasnya secara personal (Pradika, Putra, \& Noris, 2020).

Berbagai upaya baik secara kelembagaan maupun secara kultural sudah dilakukan agar pemilihan umum di Indonesia terus mengarah kepada perbaikan. Idealnya pemilukada harus dapat diselenggarakan secara optimal, menekan biaya penyelenggaraan seminimal mungkin tetapi dapat meningkatkan kualitas penyelenggaraan dengan baik.

Pada tahun 2020 terdapat kurang lebih 270 daerah yang terdiri dari 9 Provinsi, 224 kabupaten, dan 37 kota, yang akan melakukan pemilihan kepala daerah dimana terdapat perbedaan situasi karena sedang mengalami wabah internasional Corona Virus (Covid-19). Di tengah kondisi tersebut tentunya tidak menjadi pilihan yang mudah, selain biaya yang besar, kondisi dunia bahkan Indonesia sedang dirundung duka.

Keputusan telah dikeluarkan oleh Komisi Pemilihan Umum (KPU) bahwa pilkada serentak akan dilakukan pada pertengahan bulan Juli, melalui Perpu No. 022020 tentang Pilkada, KPU menyatakan bahwa Pilkada akan dihelat pada Bulan Desember 2020. Hal ini akan menimbulkan berbagai spekulasi terkait keamanan dan netralitas Pilkada (Nugraheny, 2020). Kabupaten Ponorogo merupakan salah satu diantara 224 Kabupaten yang akan menyelenggarakan Pemilukada mengingatkan hasil pilkada periode yang lalu dimenangkan oleh pasangan Ipong Mukhlison dan Sudarno, yang menjabat sebagai Bupati selama 5 (lima) tahun dan sudah habis masa baktinya (Jalil, 2019).

Perbedaan opini yang muncul baik bernada pro maupun kontra dari masyarakat umum dan juga pakar politik menggambarkan pendapat yang bersifat rasional karena didasari oleh pertimbangan serta alasan yang bersifat logis di tengah pandemi Covid-19. Diharapkan dari berbagai opini tersebut mampu mengeluarkan wawasan yang menjunjung tinggi nilai demokrasi. Sebab tidak kalah penting yaitu bagaimana pelaksanaan teknis yang menjadi tuntutan oleh kedua belah pihak yang mengeluarkan opini kepada pemerintah dapat dipertimbangkan untuk meminimalisir kebijakan yang dikeluarkan 
POLITICON : Jurnal Ilmu Politik Vol.2 No.2 ; Hal 129-148

Website : http://journal.uinsgd.ac.id/index.php/politicon ISSN : 2685-6670 ( Online )

melalui dengar pendapat dari opini-opini yang ada (Rizki \& Hilman, 2020).

Kondisi pandemi Covid-19 yang sedang dialami oleh masyarakat dunia termasuk Indonesia telah dirasakan efeknya dalam berbagai bidang, mulai dari pencanangan Physical Distancing jaga jarak fisik hingga pemberlakuan New Normal terlihat berpengaruh besar terhadap kehidupan manusia. Penjelasan diatas telah mempelihatkan bagaimana KPU-RI bersikukuh untuk menyelenggarakan Pemilukada di tengah bencana COVID 19. Berbagai skenario bisa dilakukan untuk melancarkan agenda demokrasi tahunan. Namun yang menjadi persoalan apakah skenario tersebut masuk akal terutama bagi keamanan masyarakat sehingga menjadi persoalan bersama yang harus dipikirkan secara bijak.

\section{Gambaran Hasil Pilkada tahun 2015}
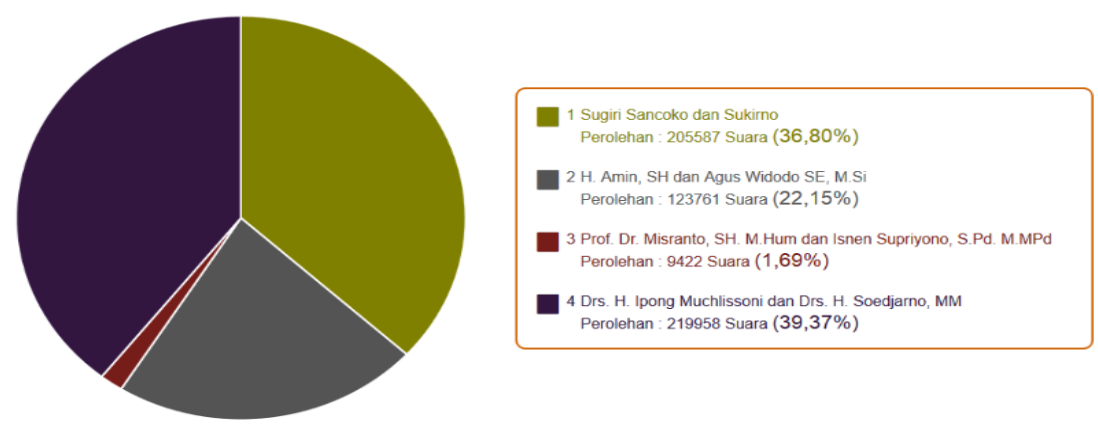

Gambar 2. Hasil perolehan suara Kabupaten Ponorogo Tahun 2015 Sumber: diolah dari (Harsono, 2018)

Kemenangan Pasangan Ipong Muchlisoni dan Sudarno tidak lepas dari peran kiai yang secara kultural membantu proses kampanye hingga pencoblosan yang menempatkan kedua pasangan memperoleh suara paling banyak diantara beberapa calon bupati yang bersaing (Diponegoro, 2016).

Strategi politik pasangan Ipong dan Sudarno terkait dengan perihal ketokohan lokal yang ada di Kabupaten Ponorogo dan juga secara kelembagaan masuk dalam berbagai komunitas untuk membangun konsensus bersama yang kemudian melambungkan pasangan ini dalam pemilihan sehingga mulai dikenal oleh masyarakat, walau pada awalnya sosok Ipong kurang Familiar karena lama merantau di pulau Kalimantan (Imanniar, 2016). 
POLITICON : Jurnal Ilmu Politik Vol.2 No.2 ; Hal 129-148

Website : http://journal.uinsgd.ac.id/index.php/politicon ISSN : 2685-6670 ( Online )

Kemenangan Pasangan Ipong dan Sudarno dalam Pilkada serentak Kabupaten Ponorogo di Tahun 2015 menggambarkan bahwa pasangan tersebut mampu melakukan strategi politik dengan baik melalui pengenalan situasi dan pendekatan secara kelembagaan dan kultural pada masyarakat di wilayah Kabupaten Ponorogo. Poin inilah yang memang menjadi kunci keunggulan mereka pada kontestasi pemilu pada tahun 2015.

Kemenangan tersebut tidak lantas memuluskan langkah pasangan terpilih tersebut untuk menduduki kursi tertinggi di Kabupaten Ponorogo. Hal ini diakibatkan oleh adanya gugatan dari pesaing yakni Sugiri dan Sukirno dengan dakwaan adanya sejumlah kecurangan dan kejanggalan ketika proses perhitungan dan pengumuman hasil Pemilihan Umum Kepala Daerah serentak (Anggoro \& Hilman, 2018).

\section{Figur serta Kandidat dalam Pilkada Ponorogo Tahun 2020}

Beberapa pemberitaan di pertengahan Tahun 2020, telah memperlihatkan jika ada beberapa kandidat kuat yang akan diproyeksikan bakal berkompetisi dalam Pemilukada (Pemilihan Kepala Daerah) Kabupaten Ponorogo yang gencar melakukan berbagai aktivitas pendekatan ke berbagai komunitas guna memperkuat dan menegaskan dirinya dalam kontestasi tersebut.

Sugiri Sancoko didukung oleh Komunitas Motor Gede (MOGE), dalam kesempatan tersebut Sugiri diundang oleh komunitas tersebut di salah satu Rumah Makan "Kampung Dawet" di daerah Siman, Jabung, Kabupaten Ponorogo. Mereka mendukung dan mendoakan pak "Giri" untuk maju sebagai calon Bupati Ponorogo periode 2021-2025 (Kamaludin \& Burhanudin, 2020). Harian Ponorogo Pos dalam Headlinenya yang bertajuk “Ipong vs Sugiri” kembali bertarung di Pilbub”, memberitakan tentang kemungkinan kedua sosok atau figur ini kembali bertarung di pemilukada tahun 2020 telah memberi gambaran tentang kemungkinan dua sosok yang diproyeksikan maju dan kembali bertarung seperti tahun lalu. Hal ini berangkat dari gerakan politik kedua tokoh yang aktif dalam periode awal 
hingga pertengahan tahun 2020 (Nanang, 2020).

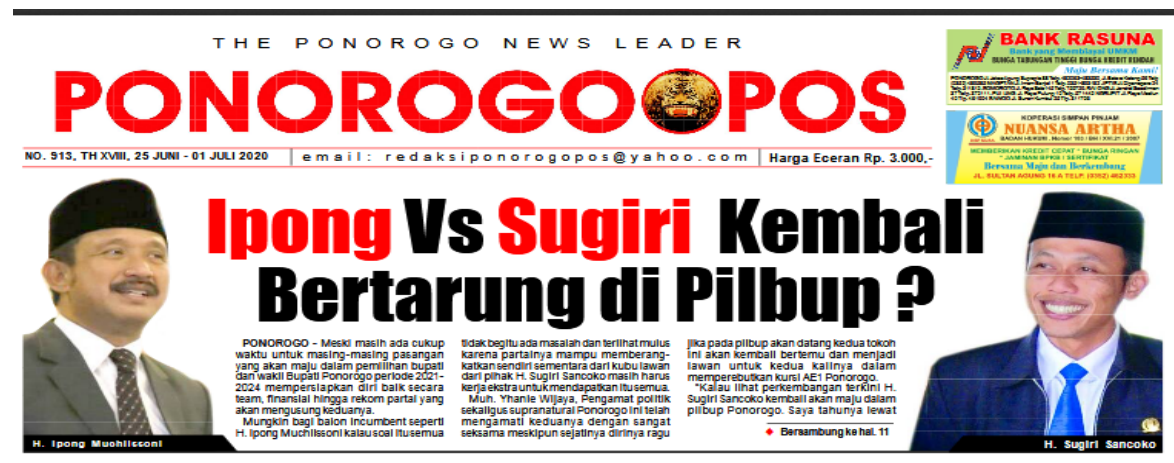

Gambar 3. Headline Harian Lokal Ponorogo Pos, dengan Tajuk “ Ipong vs Sugiri” kembali bertarung di Pilbub.

Sumber diolah dari: (Nanang, 2020).

Sugiri mendapat rekomendasi dari Partai Persatuan Pembangunan (PPP)

secara resmi setelah bermunculan suara dari arus bawah dan Dewan Pimpinan Cabang se-Kabupaten Ponorogo yang menginginkan beliau maju dari partai berlambang ka'bah (Marhaban, 2020).

Beberapa partai gurem merapat ke Ipong sebagai bentuk dukungan terhadap kontestasi pemilukada yang akan diselenggarakan pada tahun 2020 diantaranya adalah Partai Hanura dan Nasdem (Lin, 2020).

Melihat gerakan para kandidat dan juga arah koalisi, penulis berpendapat bahwa masing-masing kandidat masih memiliki peluang terbuka untuk memperkuat koalisi untuk memenangkan kontestasi pemilukada 2020. Namun kondisi tersebut diperidiksi tidak akan semeriah perhelatan periode pemilukada yang lalu karena akan dilangsungkan pada masa pandemik Covid-19.

\section{Kontestasi Pilkada Tahun 2020 di Era Pandemik Covid-19}

Pemilukada serentak akan dilakukan pada tahun 2020, sebagai agenda rutin yang telah dilakukan mulai tahun 2005 untuk pertama kali dimana pada tahun ini dilakukan dengan kondisi berbeda. Hal tersebut dikarenakan sedang mewabahnya Virus Corona (Covid-19) yang sedang melanda dunia termasuk Indonesia. Perkembangan kasus Covid-19 yang tak kunjung usai telah menimbulkan kepanikan terlebih terkait bagaimana suksesi pemimpin dan praktik demokrasi yang ada di Indonesia.

Polemik muncul ketika secara resmi pemerintah melalui Komisi 
Pemilihan Umum mengeluarkan Peraturan Komisi Pemilihan Umum PKPU No. 05 Tahun 2020 tentang perubahan ketiga atas peraturan komisi pemilihan umum No. 15 tahun 2019 tentang Tahapan, Program dan Jadwal Penyelenggaraan Pemilihan Gubernur dan Wakil Gubernur, Bupati dan Wakil Bupati, serta Walikota dan Wakil Walikota tahun 2020. Di satu sisi agenda politik terkait praktik demokrasi harus berkualitas dan juga diselenggarakan secara profesional, disisi lain harus ada pengawasan protokol kesehatan supaya penyelenggaraan Pemilukada tidak menimbulkan masalah di kemudian hari.

Menurut Ferdian Andi salah satu dosen dan juga peneliti dari Universitas Bhayangkara Jakarta yang dimuat pada harian kompas online, memaparkan bahwa pilkada di era Pandemik Covid-19 akan memunculkan beberapa tantangan, antara lain:1). Korelasi pendanaan pilkada sebagai praktik demokrasi langsung yang terkenal mahal, di sisi lain negara kita masih memerlukan pendanaan untuk penyelesaian dan penanggulangan pandemik Covid-19, 2). Indikator pelaksanaan praktik demokrasi melalui Pemilukada yang memiliki nilai wajib yang harus dipenuhi, misalnya: partisipasi, ini akan bermasalah ketika keterlibatan masyarakat menjadi terganggu, bagaimana masyarakat turut serta dalam pesta demokrasi dengan berbagai pembatasan melalui kebijakan Physical Distancing (Andi, 2020).

Persoalan esensi dari penyelenggaraan Pemilukada memang menjadi masalah kunci, dimana ada beberapa poin yang harus terwujud seperti transparansi, profesional dan bertanggung jawab. Secara logika bagaimana kemampuan pemerintah mewujudkannya melalui lembaga pemilihan dan pengawasan. Hal inilah merupakan tantangan untuk mewujudkannya (Sandi \& Suprayitno, 2020).

Tuntutan dalam penyelenggaraan Pemilukada di tengah Pandemik Covid-19 tidak hanya ditujukan kepada perangkat penyelenggara pemilu, namun juga kepada para kontestan dan pendukung calon supaya bisa menjalankan praktik demokrasi secara tertib dengan mematuhi protokol 
kesehatan yang telah diinstruksikan oleh Pemerintah Pusat sehingga benarbenar aman dan tidak menimbulkan persoalan pasca pemilihan kepala daerah. Hal ini tentu juga harus memperhatikan kondisi lokal daerah yang akan menjalani Pemilukada terkait bagaimana persebaran Covid-19 di daerah tersebut sehingga bisa dipersiapkan dengan baik dan optimal untuk mengurangi resiko.

\section{Perkembangan Covid-19 di Kabupaten Ponorogo}

Data terbaru dari Kabupaten Ponorogo terkait penyebaran Covid-19 per hari Senin tanggal 06 Juli 2020 adalah sebanyak 56 orang, dengan jumlah pasien yang diisolasi mandiri sekitar 2 orang, isolasi di RS sebanyak 19 orang dan yang meninggal dunia sebanyak 3 orang. Sedangkan yang sudah sembuh sebanyak 32 Orang, namun jumlah ini terus diperbaharui secara periodik.

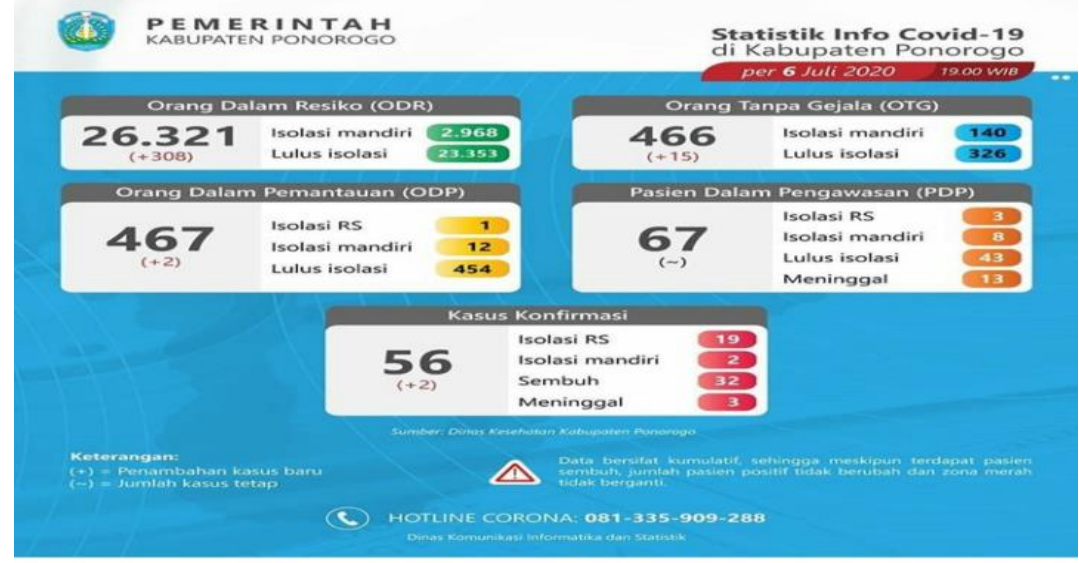

Gambar 4. Persebaran Covid-19 Per tanggal 06 Juli 2020 di Kabupaten Ponorogo Sumber diolah dari: (Ponorogo, 2020)

Peta Politik Kabupaten Ponorogo menyongsong Pemilukada tahun 2020 di tengah pandemik Covid-19 masih didominasi oleh calon Incumbent dan juga salah satu pesaing yang pada tahun 2014 ikut berkompetisi memperebutkan jabatan tertinggi di Kabupaten Ponorogo. Calon Incumbent adalah Bapak Ipong Muchlisoni yang saat ini menjabat sebagai Bupati Kabupaten Ponorogo, sedangkan yang kedua atau pesaingnya adalah Bapak Sugiri Sancoko seorang tokoh masyarakat yang pada kesempatan pilkada sebelumnya merupakan pesaing dan mengaku mendapatkan dukungan dari beberapa komunitas. Melihat pemilukada periode saat ini di tengah pandemik 
Covid-19, banyak hal yang harus diutamakan oleh pihak penyelenggara pemilu, kandidat bupati dan calon wakil bupati serta massa pendukung calon, yakni mematuhi protokol kesehatan dan juga menjaga nilai-nilai esensi dari praktik demokrasi supaya dapat terpenuhi, yakni: transparan, profesional dan dapat dipertanggungjawabkan.

Melihat pemaparan diatas, terlihat kandidat yang akan bertarung dan memiliki kekuatan pendukung adalah dua orang yakni Sugiri dan Ipong. Kedua kandidat menurut data yang tersaji memiliki peluang yang sama karena belum memperlihatkan dukungan dari partai-partai besar pemenang pemilu, selain itu masih belum terlihat arah koalisinya.

\section{SIMPULAN}

Peta Politik pada Pemilukada Kabupaten Ponorogo memunculkan dua sosok yang diprediksi maju sebagai kontestan. Sosok tersebut merupakan kontestan yang pernah berjumpa pada pilkada sebelumnya dimana kali ini mereka akan saling berkompetisi dengan kondisi yang berbeda, karena tahun ini sedang menghadapi wabah Covid-19 sebagai konsekuensi dari lahirnya aturan hukum dari pemerintah soal Pemilukada. Maka praktik demokrasi harus diselenggarakan dengan mematuhi protokol kesehatan yang disarankan dalam Pemilukada tahun 2020. Penulis belum melihat kesiapan dari berbagai komponen yang akan berpartisipasi dalam Pilkada baik bakal calon ataupun pendukung tentang standar protokol kesehatan untuk aktifitas yang akan dilakukan masing-masing kandidat.

\section{DAFTAR PUSTAKA}

Andi, F. (2020). KOMPAS.COM. Retrieved 07 07, 2020, from Pertaruhan Kualitas Pilkada 2020 di Masa Pandemi: https://nasional.kompas.com/read/2020/06/25/19572541/pertaruha n-kualitas-pilkada-2020-di-masa-pandemi?page=all

Anggoro, A. D., \& Hilman, Y. A. (2018). Kiruh Pilkada di Kabupaten Ponorogo (Analisis Wacana Kritis Model Norman Fairclough tentang Pemberitaan Gugatan Pilkada Kabupaten Ponorogo pada Tanggal 22 Desember 201521 Januari 2016). Jurnal Riset Komunikasi (JURKOM), 203 - 212. 
Aridhayandi, D. M. (2015). Putusan Mahkamah Konstitusi tentang Pemilu Serentak di Hubungkan dnegan Pencegahan Korupsi Politik. Jurnal Hukum Mimbar Justitia, 523 - 549.

Chaniago, P. S. (2016). Evaluasi Pilkada Pelaksanaan Pilkada Serentak Tahun 2015. Politik Indonesia (Indonesian Political Review), 196 - 211.

Diponegoro, A. M. (2016). Ulama Sebagai Kekuatan Politik : PeranUlamaNahdlatul Ulama dalam Kemenangan Ipong Muchlissoni di Pilkada Langsung Kabupaten Ponorogo 2015. Jakarta: Universitas Islam Negeri Syarif Hidayatulah .

Fahmi, K. (2010). Penentuan Sistem Pemilihan Umum Anggota Legislatif. Jurnal Konstitusi, 119 - 160.

Haqqani, M. I. (2020). Pemanfaatan Media sosial Intagram oleh BHABINKAMTIBMAS guna mengantisipasi penyebaran HOAX Pemilu 2019 di Polres Banyumas. Police Studiew Review, 297-372.

Hardjaloka, L. (2015). Studi Dinamika Mekanisme Pilkada di Indonesia dan Perbandingan Mekanisme Pilkada Negara Lainya. Rechtsvinding Media Pembinaan Hukum Nasional, 59 - 179.

Harsono, J. (2018). Analisis Sikap Politik Warga Muhammadiyah Ponorogo Dalam Pilkada 2015. Aristo, 81 - 98.

Hikmat, M. M. (2014). Pemetaan masalah dan Solusi Konflik lokal dalam Pilkada Langsung di Indonesia. Mimbar, 18 - 27.

Imanniar, N. O. (2016). Strategi Komunikasi Politik Pasangan Bupati dan Wakil Bupati (Ipong Muhlisoni) . Ponorogo: Universitas Muhammadiyah .

Irawan, B. B. (2007). Perkembangan Demokrasi Di Indonesia. Jurnal Ilmiah Hukum dan Dinamika Masyarakat, 54 - 64.

Jalil, A. (2019). Solopos.com. Retrieved 07 06, 2020, from https://www.solopos.com/politik-salam-dan-sapa-jadi-sarana-ipongmuchlissoni-pimpin-ponorogo-1026551

Kamaludin \& Burhanudin, M. (2020). Cakrawala 7. Retrieved 7 7, 2020, from Komunitas MOGE dukung Giri Maju Pilkada 2020: https://cakrawala7.com/komonitas-moge-dukung-giri-maju-pilkada$2020 /$

Kennedy, R., \& Suhendarto, B. P. (2020). Diskursus Hukum: Alternatif Pola Pengisian Jabatan Kepala Daerahdi Masa Pandem iCovid-19. Pembangunan Hukum Indonesia, 188 - 204. 
Lin. (2020). REALITA.co. Retrieved from Jelang Pilkada Ponorogo, Partai Gurem Mulai Ambil Sikap : http://www.realita.co/jelang-pilkadaponorogo-partai-gurem-mulai-ambil-sikap.

Marhaban, M. (2020). timesindonesia. Retrieved from Pilkada 2020, DPC PPP Ponorogo Usulkan Sugiri Sancoko sebagai Bacabup: https://www.timesindonesia.co.id/read/news/279072/pilkada-2020dpc-ppp-ponorogo-usulkan-sugiri-sancoko-sebagai-bacabup.

Nanang. (2020). Ipong Vs Sugiri Kembali Bertarung di Pilbub. Ponorogo: Ponorogo Pos.

Noviati, C. E. (2013). Demokrasi dan Sistem Pemerintahan. Konstitusi, 333354.

Nugraheny, D. E. (2020). Kompas.com. Retrieved 07 06, 2020, from https://nasional.kompas.com/image/2020/06/02/12115711/kpupastikan-tahapan-pilkada-2020-akan-dilanjutkan-pada-15-juni?page=1

Nuryanti, S. (2015). Intervensi Penyelenggaraan Pemilukada : Regulasi, Sumberdaya dan Ekseskusi. JSP (Jurnal Ilmu Sosial dan Ilmu Politik), 125140.

Ponorogo, P. K. (2020). Pemerintahan Kabupaten Ponorogo. Retrieved 07 07, 2020, from Update infografis Sebaran Covid-19 Kabupaten Ponorogo Senin, 6 Juli 2020 pukul 19.00 WIB: https://www.instagram.com/p/CCTUxJHA0FJ/?igshid=jfneamzfmyqz

Prabowo, R. E. (2011). Demokrasi Pancasila Sebagai Model. Jurnal Ilmiah CIVIS, 42-51.

Pradika, R. F., Putra, H. A., \& Noris, A. (2020). Lembaga Penyelesaian sengketa Pemilu yang ideal di Indonesia. Diversi Jurnal Hukum, 73-91.

Rahmatunnisa, M. (2017). mengapa Integritas Pemilu Penting? Bawaslu, 1 - 12.

Ramadlan, M. F., \& Tri Hendra Wahyudi. (2016). Pembiaran Pada Potensi Konflik dan Kontestasi Semu Pemilukada Kota Blitar: Analisis Institusionalisme Pilihan Rasional. Politik Indonesia (Indonesia Political Science Review, 136-153.

Rizki, S. C., \& Hilman, Y. A. (2020). Menakar Perbedaan Opini dalam Agenda Pelaksanaan Kontestasi Pilkada Serentak di Tengah COVID 19. Jurnal Ilmiah Muqoddimah, 143 - 155.

Rosana, E. (2016). Negara Demokrasi dan Hak Asasi Manusia. Jurnal Tapis, 37 $-53$. 
POLITICON : Jurnal Ilmu Politik Vol.2 No.2 ; Hal 129-148

Website : http://journal.uinsgd.ac.id/index.php/politicon ISSN : 2685-6670 ( Online )

Sandi, J. R., \& Suprayitno. (2020). Fenomena Pengawasan Pemilihan Kepala Daerah di Kalimantan Tengah Masa Pandemi COVID 19. Jurnal Politik Pemerintahan Dharma Praja, 1 - 13.

Setiabudhi, D. O. (2015). Pemilihan Kepala Daerah dalam Tinjauan Demokrasi dan Kedaulatan. Lex Administratum, 177-190.

Simamora, J. (2011). Eksistensi Pemilukada Dalam Rangka Mewujudkan Pemerintahan Daerah Yang Demokratis. Mimbar Hukum, 221-236.

Sinaga, R. S. (2012). Implikasi Distorsi Demokrasi Pada Pemilukada Terhadap Penguatan Demokrasi Lokal. Perspektif, 47-56.

Tjarsono, I. (2013). Demokrasi Pancasila dan Bhineka Tunggal Ika Solusi Integrasi. Transnasional, 881-894.

Zamili, M. (2015). Menghindar Dari Bias, Praktik Triangulasi dan Kesahihan Riset Kualitatif. Lisan Al - Hal, 283 - 304. 